\title{
CHAPTER 10 \\ The (In)Visibility of Infants and Young Children in Child Protection
}

Eunice Lumsden

\begin{abstract}
Protecting children globally is complex, with legislation, policy and procedures specific to each country. However, even when the 'voices' of infants and young children are heard, they are not always listened to, or acted upon, by protection services. This chapter critiques the global challenges of protecting infants and young children from abuse, with specific focus on English child protection systems. The discussion draws on Articles 19 and 39 of the United Nations Convention on the Rights of the Child, which are concerned with the protection of children and ensuring that intervention services are available to those who have faced adversity. The chapter will also focus on children's right to protection and what they need to be protected from, as well as exploring the prevalence of abuse and why intervening in the early childhood period is crucial for improving long-term outcomes. There is consideration of how child protection procedures facilitate (or do not) the rights of the youngest citizens to be protected by their parents or caregivers, as well as the other adults and environments they interact with.
\end{abstract}

\section{Introduction}

This chapter is concerned with the inherent challenges of child protection (CP) in early childhood (conception to the age of eight) that can render the 'voices' of infants and young children invisible to others. Even when they are heard, they are not always listened to, or acted upon, by protection services. While there have been substantial improvements globally since the United Nations Convention on the Rights of the Child (UNCRC) was introduced (United Nations (UN), 1989), our youngest global citizens continue to face adversity. Their everyday lives, well-being and lifetime outcomes continue to be affected by physical, emotional and sexual violence and neglect. However, protecting children globally is complex, with legislation, policy and procedures specific to each country. This chapter critiques these global challenges, with specific focus on the English CP system. England is one of four countries comprising the United Kingdom (UK) and has been chosen because it has a well-developed CP system, yet even when children are 'visible' in legislation, policy and procedures in England, they can be 'invisible', exemplified in this chapter by the case study of Daniel Pelka. 
In this chapter, I argue that thirty years after the UNCRC was adopted, the lived experiences of infants and young children suggest we can and must do better in addressing their rights to protection. The chapter draws on UNCRC Articles 19 and 39 (UN, 1989) which focus specifically on the protection of children and ensuring that intervention services are available to those who have faced adversity. These Articles are strengthened and amplified by General Comments 8 and 13 (United Nations Committee on the Rights of the Child (UNCRC), 2006; 2011). However, these Articles cannot be seen in isolation from global policy initiatives. Discussion also focuses on children's rights to protection, what they need to be protected from, exploration of the prevalence of abuse and why intervening in the early childhood period is crucial for improving long-term outcomes. There will be consideration of how CP procedures facilitate (or not) the rights of the youngest citizens to be protected by their parents or caregivers, as well as the other adults and environments they interact with. The chapter starts by introducing you to the case of Daniel Pelka who died in England of abuse and starvation in 2012 aged 4 years and 8 months (Table 10.1).

Table 10.1: Case Study of Daniel Pelka, with Articles 19 and 39 (UN, 1989) ABOUT HERE

\section{Protection Rights}

UNCRC Articles 19 and 39 (UN, 1989) focus on the rights of children to have safe caregivers and environments that meet their physical and emotional needs and provide appropriate interventions if they experience maltreatment (Table 10.1). Although these articles underpin this chapter, they are intertwined with other UNCRC Articles and global policy. For example, there is a global campaign to eradicate violence against children (Lenzer 2018), a commitment to provide all children with the best possible start to life has permeated the Millennium Goals (United Nations (UN), 2000) and the Sustainable Development Goals (SDGs) (United Nations (UN), 2015). SDGs 5 and 16 call for an end to violence against women and children by 2030 .

While the UNCRC aspirations and development plans are laudable, achieving them globally is challenging and may remain a work in progress. Violence against women, children and young people occurs in every society (United Nations Children's Fund (UNICEF), 2017). Increasing refugee and migrant movement as a result of conflict, natural disasters and open 
borders presents further protection issues, including '...lack of access to services, detention and family separation' (United Nations Children's Fund (UNICEF), 2018, 6). The wider issues that present protection issues lead to violence being embedded into the structure of societies; Galtung $(1969,171)$ refers to them as 'structural violence'. This situation is then manifested through inequalities of life chances and power at macro and micro levels, in different societies and by global organisations. To secure visibility of infants and young children and ensure their voices are heard requires proactive action at every stratum of society. Daniel Pelka's case exemplifies this issue. His mother was a migrant from Poland to England. Despite well-established CP systems in England, and professionals from a range of services being actively engaged with his family, Daniel Pelka was invisible and was not heard and was not protected (Table 10.1).

The urgent need for action to end structural and localised violence is reinforced further by neurodevelopmental and epigenetic research which reinforces how the impact of adversity in early childhood can last for life (Burke Harris, 2018; Black et al., 2017; Center of the Developing Child, 2016; Shonkoff and Garner, 2012). Violence not only has an immediate effect on well-being but also has intergenerational consequences (United Nations Children's Fund (UNICEF), 2006). Young children require enhanced levels of protection because of their vulnerability, and governments that have ratified the UNCRC have responsibility to protect and safeguard them (UN, 1989; UNCRC 2006; 2011). These international directives are especially important in early childhood when our youngest citizens are most vulnerable to adverse experiences impacting on their holistic development. However, protection issues in early childhood can often go undetected, especially as most abuse takes place in the home environment and infants and young children are reliant on adults around them. Moreover, while the UNCRC clearly identifies that children have the right to be heard (UN, 1989, Article 7), the World's youngest citizens are either pre-verbal, do not have the language to explain what is happening to them, or indeed know that it is wrong. Even before birth, the developing fetus can be impacted upon by the experiences of its mother (Wave Trust, 2013), and the case of Daniel Pelka illustrates this point (Table 10.1).

CP concerns can be identified by other family members, practitioners and professionals who may be engaged with the family. However, if infants and young children are not seen consistently outside the family context, their situation will remain invisible to services that could protect them. Even when $\mathrm{CP}$ issues are identified, intervening in family life and 
providing appropriate support and protection services is complex and challenging. In England, for example, where abuse is recognised and protection procedures have been activated, serious case reviews publishing the results of inquiries into cases where children have died or there has been serious abuse have evidenced that children can and do become invisible to the professionals involved (Sidebotham et al., 2016) (see Table 10.1). A range of factors affect the extent to which infants and young children are visible, including different political viewpoints about the role of the State in family life (Parton and Reid 2014), cultural and religious beliefs (Tedum and Adjo 2017) and different perceptions about how children should be disciplined (Banahene Adjei and Minka 2018). These issues are discussed further later in the chapter.

\section{Prevalence of violence against infants and young children}

Across the World, infants and young children usually reside with their families. The family home should be a place of safety for infants and young children where they are nurtured and cared for as they develop from dependency to independence. Babies need reliable nurturing caregivers to develop secure attachments; initially, this is usually their mother, though others can fulfil this role (Centre on the Developing Child, 2017). Attachment is a popular area of research and assessing attachment patterns requires an inter-disciplinary approach (Balbernie 2013; Lumsden 2018). Secure attachment occurs when primary caregivers understand and respond appropriately to cues given by the baby. Usually, attachment behaviours are triggered when the baby is distressed because they feel threatened or anxious and are not comforted successfully. Some caregivers are unable to respond, and in some situations the safe nurturing family environment is a place of adversity, where babies and young children are harmed physically, emotionally, sexually or through neglect by adults who are meant to care for them. As Landers, Da Silva Paula and Kibana (2013, 244) observe: 'The first year is the single most dangerous period in a child's life with respect to the risks to survival, not only from infectious disease but also due to abuse and neglect.' Moreover, the risks remain high for the first five years of life.

The private nature of the family home means that babies and young children's protection needs can remain invisible to CP services and their holistic development can be negatively impacted by violence in their environments and directed towards them. Some babies and young children live in volatile family environments that reflect the 'Toxic Three' of drugs, alcohol and violence (Children's Commissioner 2018; Bellis, Lowey, Leckenby, Hughes, and 
Harrison, 2014). Some young children's experiences of adversity and abuse are not only within the family. Schools, church and other organisations and institutions they attend, including early childhood settings, can be places where they experience harm perpetrated by adults, other children and young people, including their siblings (World Health Organisation (WHO) 2006; Department for Education (DfE) 2018).

War and conflict also bring new risks from which infants and young children need protection, as well as the need for services that foster their recovery from traumatic experiences (UNICEF, 2018; WHO 2006; World Health Organisation (WHO) 2018). When our youngest global citizens experience violence, they are positioned as victims, not rights holders and if they survive the conflict, they will carry the impact of their experiences to future generations (Wagner, Heft-Neal, Bhutta, Black, Burke and Bendavid. 2018). However, regardless of the focus on children's rights and the need for protection and support services, 30 years and more after the UNCRC was adopted, it is difficult to obtain exact data about the lived experiences of children globally (UNICEF, 2017). Furthermore, despite thousands of early interventions, detection and treatment, there are insufficient ' ...evidence-based solutions for CP' (SvevoCianci, Herczog, Krappman and Cook, 2011, 979). In its presentation of contemporary data about the prevalence of violence experienced by children across the World, UNICEF (2017, 21) reveals that even with Articles 19 and 39 and General Comments, 8 and 13, only 60 countries have instigated '...full legal protection from corporal punishment in the home' and very few countries have banned smacking children. UNICEF's (2017) findings reinforce the work of WHO (2006) and the British Medical Association (BMA) (2013), suggesting that CP is a serious social, legal and human rights issue that requires a public health approach. This position is reinforced by the research into adverse childhood experiences (ACES) considered later in the chapter.

Drawing on data from 30 countries, the $\operatorname{UNICEF}(2017,7)$ report identifies that almost fifty per cent of 12 to 23-month-old children are exposed to corporal punishment or verbal abuse, and that:

Three-quarters of children aged 2-4 worldwide- close to 300 million- are regularly subjected to violent discipline... by their parents or other caregivers at home, and around 6 in 10 (250 million) are subjected to physical punishment...Worldwide 1 in 4 children (176 million) live with a mother who has been a victim of intimate partner violence. 
Such abuse in childhood can have lifelong implications (Lyons-Ruth et al., 2017; Burke Harris 2018).

Obtaining data about abuse in any country can be hindered by the barriers to detecting abuse. In England, for example, which has a long history of implementing legislation and policy to protect children, the National Society of the Prevention of Cruelty for Children (NSPCC) suggest the number of children in need of protection is eight times the number that are known about (Bentley, et al., 2018; Harker, Jütte, Murphy, Bentley, Miller, and. Fitch, 2013). Bentley et al., (2018) identify the challenges in recording information and processes of how information is recorded. They also highlight the lack of the children's 'voice' about their perceptions of how safe they feel. Nevertheless, most children in England, who need intervention and protection services rightly remain in their families. Only a small percentage of children are removed permanently through a court order and placed in adoptive families (Lumsden 2018). This situation is mirrored globally, reinforcing the importance of a strengths approach to engaging with families and providing appropriate support services that foster proactive factors to reduce violence against children in the family. These factors include stable caring relationships, knowledge of the parenting tasks and how children develop, parental resilience, support for parents and social networks (Landers, Da Silva Paula and Kilbane 2013).

\section{Defining Child Abuse}

The global definition of what constitutes situations when a child may need protection is outlined in General Comment 8 and was reaffirmed and strengthened in General Comment 13 (UNCRC, 2006; 2011), which emphasises that violence against children is not acceptable and is preventable (Table 10.2)

\section{Table 10.2: Definitions}

\section{ABOUT HERE}

The international definitions inform national CP legal and policy frameworks, however, this is not implemented in a uniform way. Countries take different approaches which are influenced by political ideologies and interpretations of the rights of the child (Svevo-Cianci et al., 2011; Moss 2018). In the UK, for example, all four nations approach CP differently. Scotland and Northern Ireland have different legislation, statutory guidance and policies and, while England and Wales share the same legislation, their statutory guidance and procedures 
differ. The document for England (DfE, 2018) provides guidance about professional roles and procedures and is updated regularly, outlining how the State defines abusive situations and how agencies and professionals should work together to protect children, as well as the process for early intervention.

Definitions of child abuse used in England change as English society evolves. They have recently been broadened to include sexual exploitation, internet abuse and the impact of domestic violence. In England, however, safeguarding is seen consistently as 'Everyone's Business' (Department for Education (DfE), 2015) and 'Safeguarding and Promoting the Welfare of Children' is adopted as the umbrella term embracing:

- protecting children from maltreatment

- preventing impairment of children's health or development;

- ensuring that children are growing up in circumstances consistent with the provision of safe and effective care

- taking action to enable all children to have the best life chances

(DfE 2018, 103).

However, despite clear, shared definitions of what children need protection from, identifying, intervening and supporting families is complex. Sometimes, this complexity leads to the centrality of the child in the CP process being lost and their 'voice' going unheard. Even in countries that actively address CP, where infants and young children are visible to services, challenges of prevention, detection and intervention mean their individual experiences of adversity remain invisible. At a time of austerity this situation is heightened (Kelly, Lee, Sibieta, and Waters, 2018). For example, in England, the case study of Daniel Pelka and other serious case reviews have continually found that lack of professional communication and information sharing contributes to child deaths because of abuse (Sidebotham et al., 2016), despite clear guidance for how agencies should work together (DfE 2018). Enquires into CP issues concerning sexual abuse in early childhood settings in England have also found that poor leadership and management, lack of safeguarding training, poor qualification levels and blurred boundaries between staff and parents were contributing factors (Plymouth Safeguarding Children Board 2010; Wonnacott 2013).

Variations in how countries view their role in intervening in family life are not static and are influenced by the ruling political party's ideologies (Parton and Reid 2014). These 
differences have become more visible in contexts where numbers of migrants and refugees have increased. Migrants and refugees bring both benefits and challenges to the societies they join in relation to child-rearing practices and diverse views about what constitutes appropriate discipline for children. This can lead to challenges for CP and support services as, following migration, what may have been acceptable parental behaviour in their home country is not in their new country, for example physical punishment (Africans Unite Against Child Abuse (AFRUCA) 2012, 4). Furthermore, some migrant families may also face problems in their new countries that are factors that can lead to child abuse, including poverty, poor housing, social exclusion unemployment and low pay (BMA, 2013).

While child abuse is a global issue, most of the research into child abuse has been conducted in affluent societies (Landers, Da Silva Paula and Kilbane, 2013). If research into violence against children is to deepen our understanding about its multiple causal factors, it must explore cultural contexts and acknowledge the previous experiences of families and different parenting styles (Barn and Kirton, 2016). Since black children appear over-represented in care systems in western countries, these issues are pertinent in respect of the UNCRC and the child's visibility in CP systems. Banahene Adjei and Minka (2018) suggest that perceptions of parenting styles during investigations may have contributed to the high percentage of black children in the Canadian child welfare system. Similarly in the UK, reporting of physical abuse of black children is higher than for children from white or mixed cultural backgrounds, and they are over-represented in Serious Case Reviews (Barn and Kirton, 2016).

Understanding parenting styles and what may influence them is reinforced by Tedum and Adjo (2017) in their exploration of witchcraft which raises questions about how societies intellectualise issues concerning parenting in migrant families, including 'faith and beliefs, as well as family dynamics' (Tedum and Adjo 2017, 3). For many communities across the world faith and belief are strong components of family life, and the situation for black children in the UK is complicated further by the fact that child abuse occurs '...in a societal context that stigmatises their identities, marginalises their experiences, and fosters a racialised deficit perspective on their families' (Bernard and Harris 2016, 271).

These factors that can contribute to $\mathrm{CP}$ decision-making processes being complex and challenging, though this need not be the case. Clarification guidance from the United Nations (UN) (2008) indicates clearly that across the World, however difficult the parenting task, 
there is a distinction between 'punitive' and 'non-punitive' interventions with children. Children should not experience '...deliberate and punitive use of force to cause some degree of pain, discomfort or humiliation' (UN, 2008, 25). In other words, our youngest citizens' boundaries should enable them to flourish and develop resilience rather than increase their vulnerability through neglect and/or physical, emotional or sexual abuse.

\section{Consequences of Abuse}

Evidence about the personal and economic impact of abuse reinforces the importance of a child's right to protection. The early childhood period, especially 'From Conception to Two Years' (Wave Trust 2013; Norman 2019) is a period of exceptional, physical, emotional and brain development. The impact of abuse, neglect or adverse environments is well documented (Center on the Developing Child, 2016; Burke Harris, 2018; Wave Trust, 2018). However, those working in $\mathrm{CP}$ with children, young people and adults have always known that adverse experiences can impact negatively, and the intergenerational cycle of disadvantage is difficult to break. For example, in England Pringle and Naidoo $(1975,169)$ called for action to break the '...vicious cycle of the emotionally and intellectually deprived children of today becoming tomorrow's parents of yet another generation of deprived children.' They were writing nearly 45 years ago, before the UNCRC was published (UN, 1989) and before the 1989 Children Act (Department of Health (DoH, 1989) came into force in England to shift parents' rights over their children to responsibilities. UNCRC (UN, 1989) and the Children Act (DoH 1989) made children rights holders whose individual needs were paramount in decision-making process affecting them.

Decades later, ongoing research in neuroscience and molecular biology are shedding greater light into child development, especially how the brain develops and responds to environmental factors. Stress experienced by living in adverse, toxic environments impacts negatively on the development of resilience: although some level of stress is needed to develop resilience, prolonged, unpredictable and severe exposure promotes vulnerability that can lead to long term physical and mental health problems (Perry, 2018; Wave Trust, 2018). Recent research into epigenetics provides valuable new insights into childhood adversity leaving a biological, lifelong impact and how this can be mediated (Champagne 2018). This deeper understanding reinforces the vital role of prevention: if infants and young children are to be visible and their UNCRC rights upheld, parental support and appropriate family services that facilitate protective behaviours need to be prioritised. This must be done in 
conjunction with policies that address the structural inequalities that perpetuate the role of social injustice identified by Galtung (1969) that lead to violence and the abuse of power at all levels of society.

\section{Making the Invisible Visible}

Ensuring the visibility of infants and young children is not just about the violence directed towards them. It is also about the structural inequality and the power imbalances of the societies they live in and the wider adversity they experience, even before they are born. CP not only relies on legislation, policy and procedures but on ensuring those working alongside children and families have appropriate knowledge, skills, attributes and the continual desire for professional development. The case study of Daniel Pelka (Table 10.1) raises challenging issues about the role of services involved with families and barriers that prevent $\mathrm{CP}$ and render specific child invisible in complex family situations. In his short life, there were numerous opportunities when intervention could have led to less tragic outcomes for this family.

Working to combat adversity is challenging, personally and professionally. Not only is direct work with children and families complex but so also is the task of addressing incongruity that often exists between political rhetoric, policy development, research evidence and services for families. For example, in England, at the start of the new millennium, following consultation with children, government recognised in law and policy that 'Every Child Matters' and adopted an integrated approach to working with children and families (Department for Education and Skills (DfES) 2004a; 2004b). In 2010, the new Coalition Government between the Conservative and Liberal political parties, made sweeping changes and removed the language of 'Every Child Matters' from common usage (Fitzgerald, Kay and Baldock 2016). Although early childhood has continued to be a focus of policy development in England, since 2010, the context has been a very different policy direction. While children helped to develop the 'Every Child Matters' agenda, in accordance with the UNICRC Article 12 (UN, 1989), they were not consulted about its removal, so their voices were rendered invisible.

Participation by our youngest citizens involves us listening to their non-verbal as well as verbal communication. Those who work alongside them need to be 'Safe Practitioners' who understand their role in supporting young children and their parents as well as the importance 
of ongoing training in CP that provides a confident workforce (Lumsden 2018; Norman 2019). Those working in the Early Childhood Education and Care (ECEC) sector also need a strengths approach to young children's holistic development. They cannot be responsible for the home environments of those in their care, but they are responsible for the environments they provide. This includes the quality and training of staff, how they listen to and promote the voice of the child and ensure young children's participation in the services they are using.

Parents, family and community need to be proactively nurtured through policy, procedures and practice and there are examples across the globe where parenting programmes are making a difference (Landers, Da Silva Paula and Kilbane (2013). Parents and caregivers need to be enabled in their role, with services to enhance their parenting skills and practitioners and professionals who have the appropriate knowledge, skills and qualifications to support them. If infants and young children are to become more visible, parents and those working with them need to understand the intergenerational consequences and structural influences that perpetuate the need to protect them from violence and exploitation.

\section{Conclusion}

This chapter has addressed issues that suggest that we can and must do better in addressing the rights to protection of infants and young children, decades on from the adoption of the UNCRC (UN, 1989). As UNICEF (2018) and WHO (2018) have reported, millions of infants are born into adverse environments globally. Not only are infants and young children abused within their families, but ongoing global violence and structural inequalities create toxic environments which adversely affect their immediate and lifelong development. Adverse childhood experiences have lifelong and intergenerational consequences not only for the individual but for society (Burke Harris, 2018). We also have global jurisprudence and political rhetoric about the importance of the Early Childhood period and the vital role of protection services (Wave Trust, 2012; Leadsom, Field, Burstow and Lucas, 2013). However, although almost every country has ratified the UNCRC (UN, 1989), we still do have a sustained global approach that has placed children's rights at the centre of all we do. At every milestone since 1989, the same issues about the importance of ending violence against the youngest global citizens have been addressed. Yet, while the experiences of some are visible, the work of UNICEF (2017) and the case study of Daniel Pelka reinforce that much that is unknown about the violence experienced by infants and young children: they are often invisible. 
This chapter, therefore, ends with more questions than answers about how we can protect children effectively from violence and its life-long consequences at every level of society. Millions of infants and young children continue to live with structural inequality and violence. They are neglected and physically, emotionally and sexually abused by their parents, caregivers or in institutions they attend. Thousands die each year as a result or are impaired for life. The violence they experience often occurs in the privacy of their home environments, places where they should be safe and receive nurturing care. Solutions at a political level are possible, if policies for children and families are developed across political divides and funding is allocated for longer than specific financial cycles. Sustained services for families are vital for providing a highly trained, ambitious and tenacious workforce, that is maintained even in times of austerity. Infants and young children are rights holders and should be protected from abuse and need access to services that enhance the quality of their lives. Up to this point, many of their 'voices' have remained invisible at every level of society.

\section{References}

Africans Unite Against Child Abuse (AFRUCA). 2012. What is Physical Abuse? London: AFRUCA.

Balbernie, Robin. 2013. "The Importance of Secure Attachment for Infant Mental Health." Journal of Health Visiting, 1: 210 - 217, doi: 10.12968/johv.2013.1.4.210

Banahene Adjei, P. and Eric Minka. 2018. "Black Parents ask for a Second Look: Parenting under 'White' CP Rules in Canada." Children and Youth Services Review, 94: 511-524, doi: 10.1016/j.childyouth.2018.08.030

Barn, Ravinder and Derek Kirton. 2016. "Safeguarding Black Children.” In Safeguarding Black Children: Good Practice in Child Protection, edited by Claudia Bernard and Perlita Harris, 111-127. London: Jessica Kingsley.

Bellis, A. M., H. Lowey, N. Leckenby, K. Hughes, K. and D. Harrison. 2014. "Adverse Childhood Experiences: Retrospective Study to Determine their Impact on Adult Health Behaviours and Health Outcomes in a UK population." Journal of Public Health, 36 (1): 8191, doi: 10.1093/pubmed/fdt038

Bentley, Holly, Andy Burrows, Laura Clarke, Abbie Gillgan, Jazmin Glen, Maria Hafizi, Fiona Letendrie, Pam Miller, Orla O'Hagan, Priya Patel, Jessica Peppiate, Kate Stanley, Emily Starr, Nikki Vasco and Janaya Walker, 2016) "How Safe are our Children?" London: NSPCC. 
Bernard, Claudia, and Perlita Harris. 2016. "Concluding Remarks." In Safeguarding Black Children: Good Practice in Child Protection, edited by Claudia Bernard and Perlita Harris, 271-273. London: Jessica Kingsley.

Black, Maureen, Susan Walker, Lia C.H. Fernald, Christopher Andersen, Ann Digirolamo, Li Chunling, Dana Charles Mccoy, Gunther Fink, Yusra Shawar, Jeremy Shiffman, Amanda Devercelli, Quentin Wodon, Emily Vargas Baron, and Sally Grantham-Mcgregor. 2017. "Advancing Early Childhood Development: From Science to Scale 1 Early Childhood Development Coming of Age: Science through the Life Course." Lancet, 389 (10064): 7790, doi: 10.1016/S0140-6736(16)31389-7

Burke Harris, Nadine. 2018. The Deepest Well: Healing the Long-term Effects of Childhood Adversity. London: Bluebird.

British Medical Association Board of Science (BMA). 2013. Growing Up in the UK: Ensuring a Healthy Future for our Children. London: British Medical Association Board of Science.

Center on the Developing Child. 2016. From Best Practices to Breakthrough Impacts: A Science-based Approach to Building a more Promising Future for Young Children and Families. Cambridge, MA: Centre on the Developing Child.

Center on the Developing Child. 2017. "8 Things to Remember about Child Development." Cambridge: Centre on the Developing Child.

https://developingchild.harvard.edu/resources/8-things-remember-child-development/

Champagne, Frances A. 2018. "Epigenetic and Multigenerational Impact of Adversity." In Violence Against Children: Making Human Rights Real, edited by Gertrud Lenzer, 193-209. Abingdon: Routledge.

Children's Commissioner. 2018. "Estimating the Number of Vulnerable Babies. London: Office of the Children's Commissioner for England." https://www.childrenscommissioner.gov.uk/wp-content/uploads/2018/10/Estimating-thenumber-of-vulnerable-infants.pdf

Coventry Local Safeguarding Children Board. 2013. "Serious Case Review RE: Daniel Pelka." https://cscb-new.co.uk/downloads/Serious\%20Case\%20Reviews\%20$\% 20$ exec. $\% 20$ summaries/SCR Archive/Coventry\%20SCR\%20\%20Daniel\%20Pelka\%20(2013).pdf

Department for Education (DfE) 2015). "What to do if You're Worried a Child is Being Abused Advice for Practitioners." London: HMSO.

Department for Education (DfE). 2018. "Working Together to Safeguard Children." https://assets.publishing.service.gov.uk/government/uploads/system/uploads/attachment data /file/729914/Working_Together_to_Safeguard_Children-2018.pdf

Department for Education and Skills (DfES). 2004a. Children Act 2004. London: HMSO. 
Department for Education and Skills (DfES). 2004b. Every Child Matters: Change for Children. London: HMSO.

Department of Health (DoH). 1989. Children Act 1989. London: HMSO.

Fitzgerald, Damien, Janet Kay, and Peter Baldock. 2016. Understanding Early Years Policy. 4e. London: Sage Publications Ltd.

Galtung, Johan. 1969. "Violence, Peace and Peace Research." Journal of Peace Research, 6 (3): 167-191. doi.org/10.1177/002234336900600301

Harker, Lisa, Sonja Jütte, Tom Murphy, Holly Bentley, Pam Miller, and Kate Fitch. 2013. "How Safe are our Children?" https://www.nspcc.org.uk/globalassets/documents/researchreports/how-safe-children-2013-report.pdf

Kelly, Elaine, Tom Lee, Luke Sibieta, and Tom Waters. 2018. "Public Spending on Children in England Institute for Fiscal Studies." https://www.childrenscommissioner.gov.uk/wpcontent/uploads/2018/06/Public-Spending-on-Children-in-England-CCO-JUNE-2018.pdf

Landers, Cassie, Clarice Da Silva E. Paula, and Theresa Kilbane. 2013. "Preventing Violence Against Young Children." In Handbook of Early Childhood Development Research and its Impact on Global Policy, edited by Pia Rebello Britto, Patrice L. Engle and Charles M. Super, 242-259. New York: Oxford Press Limited.

Leadsom, Andrea, Frank Field, Paul Burstow, and Caroline Lucas. 2013. The 1001 Critical Days: The Importance of Conception to the Age of Two Period. London: APPG Conception to the Age of Two.

Lenzer. Gertrud. (Ed.). 2018. Violence Against Children: Making Human Rights Real. Abingdon: Routledge.

Lumsden, Eunice. 2018. Child Protection in the Early Years: A Practical Guide. London: Jessica Kingsley Publications.

Lyons-Ruth, Karlen, Jody Todd Manly, Tuula Tamminen, Robert Emde, Hiram Fitzgerald, Campbell Paul, Miri Keren, Astrid Berg, Maree Foley, and Hisako Watanabe. 2017. " The Worldwide Burden of Infant Mental Health and Emotional Disorder Report of the Task Force of the World Association for Infant Mental Health." Infant Mental Health Journal, 38 (4): 19, doi:10.1002/imhj.21674.

Moss, Peter. 2018. Alternative Narratives in Early Childhood: An Introduction for Students and Practitioners. Abington: Routledge.

Norman, Amanda. 2019. From Conception to Two Years: Development, Policy and Practice. Abington: Routledge.

Parton, Nigel, and James Reid. 2014. "The Recent History of Central Government Guidance about CP." In Safeguarding and Protecting Children in the Early Years, edited by James Reid and Steven Burton, 13-34. Abington: Routledge. 
Perry, Bruce and Maia Szalavitz. 2017. The Boy who was Raised as a Dog. 3e. New York: Basic Books.

Plymouth Safeguarding Children's Board. 2010. Serious Case Review into the Abuse at Little Ted's Nursery. Plymouth: Plymouth Safeguarding Children's Board.

Pringle, Mia, and Sandhya Naidoo. 1975. Early Child Care in Britain. London: Gordon and Breach.

Shonkoff, Jack, and Andrew Garner. 2012. "The Lifelong Effects of Early Childhood Adversity and Toxic Stress." American Academy of Paediatrics. 129: 232-246, doi: 10.1542/peds.2011-2663.

Sidebotham, Peter, Marion Brandon, Sue Bailey, Pippa Belderson, Jane Dodsworth, Jo Garstang, Elizabeth Harrison, Ameeta Retzer, and Penny Sorensen. 2016. "Pathways to Harm, Pathways to Protection: A Triennial Analysis of Serious Case Reviews 2011 to 2014 Final Report."

https://www.gov.uk/government/uploads/system/uploads/attachment_data/file/533826/Trienn ial_Analysis of SCRs_2011-2014__ Pathways to harm and protection.pdf

Svevo-Cianci, K.A., M. Herczog; L. Krappmann, and P. Cook. 2011. "The new UN C+-RC General Comment 13: "The Right of the Child to Freedom from all Forms of Violence"Changing how the World Conceptualizes CP." Child Abuse and Neglect. 35 (12): 979-989, doi: 10.1016/j.chiabu.2011.09.006

Tedam, Prospera and Awura Adjoa. 2017. The W Word: Witchcraft Labelling and Child Safeguarding in Social Work Practice. St Albans: Critical Publishing.

United Nations (UN). 1989. UN Convention on the Rights of the Child. Geneva: United Nations.

United Nations (UN). 2000. "Millennium Development Goals." http://www.un.org/en/mdg/summit2010/pdf/List\%20of\%20MDGs\%20English.pdf

United Nations. 2008. Report on the Committee on the Rights of the Child. New York: United Nations.

https://www.iom.int/jahia/webdav/shared/shared/mainsite/policy and research/un/63/A_63 41.pdf

United Nations (UN). 2015. "Sustainable Development Goals."

https://sustainabledevelopment.un.org/?menu=1300

United Nations Committee on the Rights of the Child (UNCRC). 2006. "General Comment No. 8: The right of the child to protection from corporal punishment and other cruel or degrading forms of punishment. $\mathrm{CRC} / \mathrm{C} / \mathrm{GC} / 8$."

https://www.refworld.org/docid/460bc7772.html

United Nations Committee on the Rights of the Child (UNCRC). 2011. "General Comment No. 13: The right of the child to freedom from all forms of violence. CRC/C/GC/13." https://www.refworld.org/docid/4e6da4922.html 
United Nations Children's Fund (UNICEF). 2017. "A Familiar Face: Violence in the Lives of Children and Adolescents."

https://www.unicef.org/publications/files/Violence in the lives_of_children_and_adolescent $\underline{\text { s.pdf }}$

United Nations Children's Fund (UNICEF). 2018. "UNICEF Humanitarian Action for Children."

https://unicef.at/fileadmin/media/Infos und_Medien/Aktuelle_Studien_und Berichte/2018/U NICEF Humanitarian Action for Children 2018 Overview ENG.PDF

Wagner, Zachary, Sam Heft-Neal, Zuliqar A. Bhutta, Robert E. Black, Marshall Burke and Eran Bendavid. 2018 "Armed conflict and child mortality in Africa: a geospatial analysis." The Lancet, 392, 10150, 56: 857-865.

Wave Trust. 2013. "Conception to the Age of 2: The Age of Opportunity." London: Wave Trust.

Wave Trust. 2018. "Age 2 to 18: Systems to Protect Children from Severe Disadvantage." London: Wave Trust.

Wonnacott, Jane. 2013. Serious Case Review Under Chapter VIII Working Together to Safeguard Children In respect of the Serious Injury of Case No.2010-11/3. Birmingham: Birmingham Safeguarding Children Board.

World Health Organization (WHO). 2018. "Violence against Children." http://www.who.int/mediacentre/factsheets/violence-against-children/en/

World Health Organization (WHO). 2006. "Preventing Child Maltreatment: A Guide to Taking Action and Generating Evidence." www.who.int/violence injury prevention 